\title{
PEMANFAATAN EKSTRAK AIR RIMPANG JAHE MERAH (Zingiber officinale Linn. var. rubrum) PADA BIOSINTESIS SEDERHANA NANOPARTIKEL PERAK
}

\author{
Yuli Haryani*, Ganis Fia Kartika, Yuharmen, Eka Marissa Putri, Dhia Tijani Alchalish, Yonatha \\ Melanie
}

Jurusan Kimia, Fakultas Matematika dan Ilmu Pengetahuan Alam, Universitas Riau, Kampus Bina Widya Pekanbaru, 28293, Indonesia

*Alamat Korespondensi: yuli.haryani@lecturer.unri.ac.id

\begin{abstract}
Abstrak: Penelitian ini bertujuan untuk melakukan biosintesis nanopartikel perak menggunakan ekstrak rimpang jahe merah sebagai pereduksi pada suhu ruang. Sintesis dilakukan dengan pengadukan pada shaker (150 rpm) dan tanpa pengadukan dengan rasio ekstrak dan larutan $\mathrm{AgNO}_{3} 1: 1 ; 1: 3 ; 1: 4 ; 1: 5 ; 1: 10$ dan 1:20 pada berbagai rentang waktu pengamatan. Hasil memperlihatkan bahwa metabolit sekunder pada ekstrak jahe merah mampu mereduksi $\mathrm{Ag}^{+}$menjadi $\mathrm{Ag}^{0}$ dan membentuk nanopartikel perak yang diindikasikan dengan adanya perubahan warna larutan. Nanopartikel perak dikarakterisasi menggunakan spektrofotometer UV-Vis dan absorbansi maksimum terukur di sekitar $450 \mathrm{~nm}$. Secara keseluruhan, sintesis dengan pengadukan menghasilkan produk dengan waktu yang lebih singkat dibanding tanpa pengadukan.
\end{abstract}

Kata kunci: Biosintesis, nanopartikel perak, Zingiber officinale Linn. var. rubrum

Abstract: In the present study, biosynthesis of silver nanoparticle was carried out using rhizome water extract of Zingiber officinale Linn. var. rubrum at room temperature. Different ratio of water extract and AgNO3 solution $(1: 1 ; 1: 3 ; 1: 4 ; 1: 5 ; 1: 10$ dan 1:20) were applied at static condition and under agitation (150 rpm). Different contact times were applied for each condition. The results showed $\mathrm{Ag}^{+}$has been reduced to $\mathrm{Ag}^{0}$ by secondary metabolites that was confirmed by colour changes of the solution. The product of silver nanoparticles were then characterized using spectrophotometer UV-visible which was yielded a peak at $450 \mathrm{~nm}$. Overall, the formation of silver nanoparticle under agitation was faster than the process at static condition.

Keywords: Biosynthesis, silver nanoparticle, Zingiber officinale Linn. var. rubrum

\section{PENDAHULUAN}

Nanoteknologi didefinisikan sebagai ilmu yang berhubungan dengan material yang berukuran 1 hingga $100 \mathrm{~nm}$, memiliki sifat yang berbeda dari bahan asalnya dan memiliki kemampuan untuk mengontrol atau memanipulasi dalam skala atom sehingga dimungkinkan dapat dibuat material berukuran nano yang disebut nanopartikel (Sharma et al. 2009). Nanopartikel yang telah dikembangkan adalah berupa nanopartikel logam, oksida logam, semikonduktor, polimer, dan material karbon (Nagarajan \& Horton 2008). Nanopartikel logam paling banyak diteliti karena kemudahannya untuk disintesis dan aplikasinya yang luas sebagai obatobatan, detektor, katalis, zat pelapis permukaan, dan antibakteri (Feldheim \& Foss 2002). Beberapa nanopartikel logam diantaranya dari perak, emas, seng, tembaga, dan titanium (Nagarajan \& Horton 2008).

Mallikarjuna et al. (2012) melaporkan bahwa nanopartikel perak adalah yang paling banyak diteliti dan aplikasinya luas di bidang biologi, kedokteran, dan farmasi. Nanopartikel perak memiliki keunggulan sebagai substansi antimikroba, anti inflamasi, anti angiogenesis, anti jamur, anti viral, dan anti aktivitas platelet (Mitra et al. 2012).

Metode reduksi kimia merupakan metode yang sering digunakan dengan mereduksi garam perak oleh natrium sitrat atau natrium borohidrat (Sondik \&
Salopek 2004). Namun penggunaan bahan kimia pada sintesis nanopartikel perak mengakibatkan teradsorpsinya bahan kimia beracun (agen pereduksi, pelarut organik) pada permukaan material sehingga akan berdampak merugikan dan berbahaya pada aplikasinya (Singh et al. 2010).

Metode biosintesis dapat dipilih untuk mengatasi masalah tersebut karena prinsip biosintesis adalah memanfaatkan tumbuhan dan mikroorganisme sebagai agen pereduksi (Solomon et al. 2007). Pemanfaatan tumbuhan dalam biosintesis nanopartikel melibatkan kandungan senyawa metabolit sekunder sebagai agen pereduksi (Jirovetz et al. 2003).

Jahe merah (Zingiber officinale Linn. var. rubrum) merupakan tanaman yang melimpah di Indonesia. Tanaman tersebut mengandung beberapa metabolit sekunder berupa flavonoid, fenolik, terpenoid, keton, dan aldehid (Natta et al. 2008). Penelitian terdahulu memperlihatkan bahwa minyak atsiri jahe merah sangat bermanfaat dalam bidang kesehatan dan memiliki aktivitas antibakteri, namun tidak untuk ekstrak air nya (Yuharmen dkk. 1998).

Ekstrak air rimpang jahe merah mengandung homolog fenolik keton yang dikenal sebagai gingerol, yaitu senyawa turunan fenol (Mishra 2009). Otari et al. (2014) menambahkan bahwa biomolekul seperti fenolik, terpenoid, seskuiterpen, dan flavonoid yang ada pada ekstrak tanaman berperan sebagai agen 
pereduksi nanopartikel perak. Untuk melihat kemampuan metabolit sekunder pada ekstrak air jahe merah sebagai reduktor dan peningkatan aktivitas antibakteri setelah terbentuk nanopartikel perak, pada penelitian ini telah dilakukan biosintesis nanopartikel perak menggunakan ekstrak air rimpang jahe merah secara sederhana pada suhu ruang dan dibandingkan dengan penggunaan shaker.

\section{BAHAN DAN METODE}

\section{Alat dan Bahan}

Alat dan bahan yang digunakan pada penelitian ini adalah spektrofotometer UV-Vis (Thermoscientific Genesys 10), microcentrifuge (HITACHI), Vortex (H-VM-300), shaker (Barnstead, Lab-Line), neraca analisis (Mettler AE 200), rotary evaporator (Rotavapor Buchir-114), perak nitrat $\left(\mathrm{AgNO}_{3}\right.$, Merck, Cat. No. DL0593), akuades, dan rimpang jahe merah yang diperoleh dari pasar tradisional Arengka, Kota Pekanbaru, Provinsi.

\section{Ekstraksi rimpang jahe merah}

Rimpang jahe merah diperoleh dari salah satu pasar tradisional Kota Pekanbaru. Rimpang tersebut dicuci hingga bersih dengan akuades dan aqua DM, dipotong-potong, dan diambil sebanyak 150 gram, lalu direbus dengan $250 \mathrm{~mL}$ akua demineralisata dalam erlenmeyer $500 \mathrm{~mL}$. Selanjutnya, rebusan dibiarkan mendidih selama 5 menit dan kemudian dilakukan proses ultrasonikasi selama 30 menit. Setelah mencapai suhu ruang, air rebusan dituang dan disaring dengan menggunakan kertas saring. Ekstrak air rebusan tersebut selanjutnya digunakan langsung untuk biosintesis nanopartikel perak.

\section{Sintesis nanopartikel perak \\ Sintesis nanopartikel perak dilakukan menggunakan larutan $\mathrm{AgNO}_{3} \quad 10^{-3} \mathrm{M}$ sebagai}

prekursor dan agen pereduksinya adalah ekstrak air rimpang jahe merah. Sintesis dilakukan dengan mereaksikan ekstrak dan larutan $\mathrm{AgNO}_{3}$ dengan perbandingan volume yaitu 1:1, 1:3, 1:4, 1:5, 1:10, dan 1:20. Sintesis ini dilakukan pada suhu ruang dan diamati selama 45 jam.

Untuk tabung-tabung pembanding sintesis menggunakan shaker, dimasukkan ke dalam incubator shaker pada suhu ruang dengan kecepatan $150 \mathrm{rpm}$. Perubahan warna yang merupakan indikasi terbentuknya nanopartikel diamati pada setiap menit ke-60 dan dilakukan karakterisasi menggunakan Spektro-fotometer UV-VIS. Selanjutnya dilihat perubahan warna koloid nanopartikel perak.

\section{Karakterisasi nanopartikel perak}

Absorbansi hasil sintesis diukur dengan spektrofotometer UV-VIS, Spektrum absorpsi diamati pada panjang gelombang 300-700 nm. Kestabilan nanopartikel perak diamati berdasarkan perubahan $\lambda_{\text {maks }}$ pada waktu-waktu tertentu dengan spektrofotometer UV-VIS.

\section{HASIL DAN PEMBAHASAN}

Biosintesis nanopartikel perak dilakukan dengan memanfaatkan bahan alam seperti ekstrak tanaman sebagai zat pereduksi $\mathrm{Ag}^{+}$menjadi $\mathrm{Ag}^{0}$. Metode ini bertujuan agar proses pembentukan nanopartikel lebih ramah lingkungan dan tidak membutuhkan banyak bahan kimia (Elumalai et al. 2011). Proses reduksi $\mathrm{Ag}^{+}$menjadi $\mathrm{Ag}^{0}$ tidak lepas dari peran senyawa tertentu yang bersifat bioreduktor. Kesharwani et al. (2009) dan Shankar et al. (2004) melaporkan bahwa metabolit sekunder seperti fenolik, terpenoid, flavonoid, dan biomolekul yang memiliki gugus fungsi aldehid, asam karboksilat, dan amida merupakan senyawa yang berperan dalam mengkonversi $\mathrm{Ag}^{+}$menjadi $\mathrm{Ag}^{0}$.

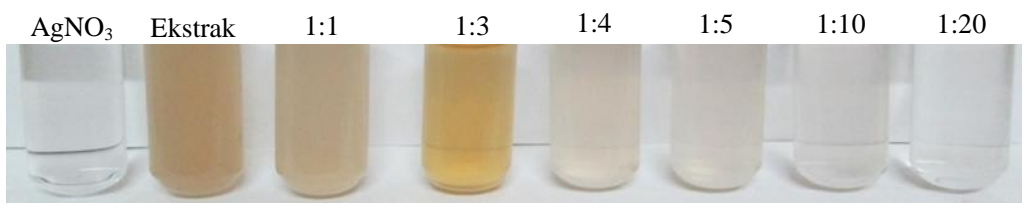

a. 0 jam

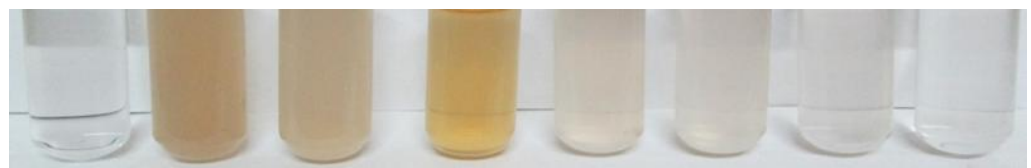

b. 9 jam

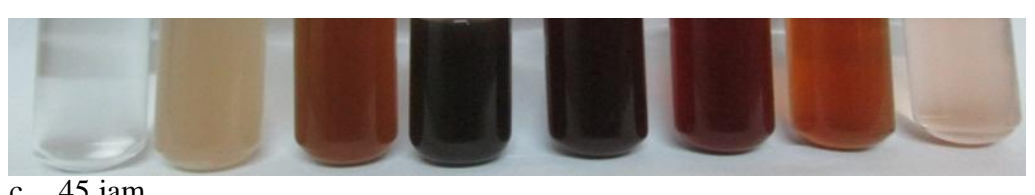

c. 45 jam

Gambar 1. Perubahan warna yang terjadi pada sintesis suhu ruang tanpa pengadukan 
Pada penelitian ini, biosintesis dilakukan dengan cara mencampurkan ekstrak dengan larutan $\mathrm{AgNO}_{3}$ $10^{-3} \mathrm{M}$ pada suhu ruang dengan kontak biasa dan dengan pengadukan pada kecepatan $150 \mathrm{rpm}$. Untuk menentukan kondisi optimum, digunakan variasi rasio perbandingan ekstrak dan larutan $\mathrm{AgNO}_{3} 10^{-3} \mathrm{M}$ v/v yaitu $1: 1 ; 1: 3 ; 1: 4 ; 1: 5 ; 1: 10$ dan $1: 20$ serta variasi waktu kontak selama 0 hingga 45 jam untuk kontak biasa dan 0 jam, 9 jam, 11 jam, 13 jam, 17 jam, serta 19 jam untuk sintesis dengan pengadukan.

Terbentuknya nanopartikel perak secara visual ditandai dengan terjadinya perubahan warna dari bening menjadi kuning hingga coklat kehitaman. Untuk ke dua kondisi sintesis, perubahan warna awal terbentuk pada jam ke-9. Perubahan warna pada proses biosintesis diperlihatkan pada Gambar 1 .

Terjadinya perubahan warna koloid pada pembentukan nanopartikel perak disebabkan oleh proses oksidasi reduksi. Senyawa organik yang terdapat pada ekstrak air rimpang jahe merah berperan sebagai agen pereduksi sehingga senyawa organik tersebut mengalami oksidasi dan $\mathrm{Ag}^{+}$adalah ion yang direduksi menjadi $\mathrm{Ag}^{0}$. Warna awal campuran ekstrak dan $\mathrm{AgNO}_{3} \quad 10^{-3} \mathrm{M}$ adalah keruh (warna ekstrak) dan berubah menjadi kuning muda, kuning tua, coklat hingga coklat kehitaman.

Warna yang terbentuk dari proses sintesis nanopartikel perak berasal dari senyawa organik yang teroksidasi (Elumalai et al. 2011). Semakin pekat warna yang dihasilkan menunjukkan semakin banyak senyawa organik yang teroksidasi dan semakin banyak pula $\mathrm{Ag}^{+}$yang mengalami reduksi menjadi $\mathrm{Ag}^{0}$, semakin meningkat konsentrasi nanopartikel perak yang terbentuk. Perubahan warna ini sesuai dengan penelitian sebelumya yang dilakukan oleh Lee et al. (2006) dan Chandran et al. (2006) bahwa terbentuknya nanopartikel perak ditandai dengan perubahan warna dari tidak berwarna menjadi kuning hingga coklat tua. Kesharwani et al. (2009) dan Shankar et al. (2004) juga melaporkan bahwa metabolit sekunder seperti fenolik, terpenoid, flavonoid dan biomolekul yang memiliki gugus fungsi aldehid, asam karboksilat dan amida merupakan senyawa yang berperan dalam mengkonversi $\mathrm{Ag}^{+}$menjadi $\mathrm{Ag}^{0}$.

Analisis spektrum UV-Vis dapat mengkonfirmasi terbentuknya nanopartikel perak. Hasil analisis menggunakan spektrofotometer UV-Vis ditampilkan dengan puncak Surface Plasmon Resonance (SPR). Umumnya puncak SPR dipengaruhi oleh ukuran, bentuk, morfologi, komposisi, dan sifat dielektrik lingkungan di sekitar sistem (Kelly et al. 2003). Koloid nanopartikel perak berupa hidrosol yaitu fase terdispersinya padatan dalam medium pendispersi berupa cairan. Koloid nanopartikel perak memiliki puncak serapan pada panjang gelombang sekitar 405$500 \mathrm{~nm}$.

Pada penelitian ini, pengukuran absorbansi nanopartikel perak menggunakan spektrofotometer UV-Vis dilakukan pada rentang panjang gelombang 300-700 nm. Untuk sintesis tanpa pengadukan, pengamatan dilakukan selama 45 jam dan absorbansi diukur tiap 3 jam. Hasil biosintesis menggunakan ekstrak air rimpang jahe merah dengan larutan $\mathrm{AgNO}_{3}(\mathrm{v} / \mathrm{v}) 1: 1 ; 1: 3 ; 1: 4 ; 1: 5 ; 1: 10$ dan 1:20 memiliki serapan maksimum berturut-turut pada panjang gelombang 402, 404, 412, 211, 417 dan 419 nm. Kondisi optimum diperlihatkan oleh kurva jam ke 36 untuk rasio 1:10 (Gambar 2).

Gambar 3 adalah spektrum absorpsi hasil karakterisasi produk nanopartikel perak dengan pengadukan yang memperlihatkan adanya puncak absorpsi pada panjang gelombang $450 \mathrm{~nm}$. Pada jam ke-9 setelah sintesis, larutan nanopartikel perak memiliki absorbansi maksimum kurang dari 0,5. Tetapi, pada jam ke-19 semua koloid nanopartikel perak memiliki absorbansi maksimum lebih dari 0,5. Pengadukan jam ke-17 memperlihatkan kurva yang lebih mulus tanpa gerigi dibandingkan waktu pengadukan yang lebih panjang.

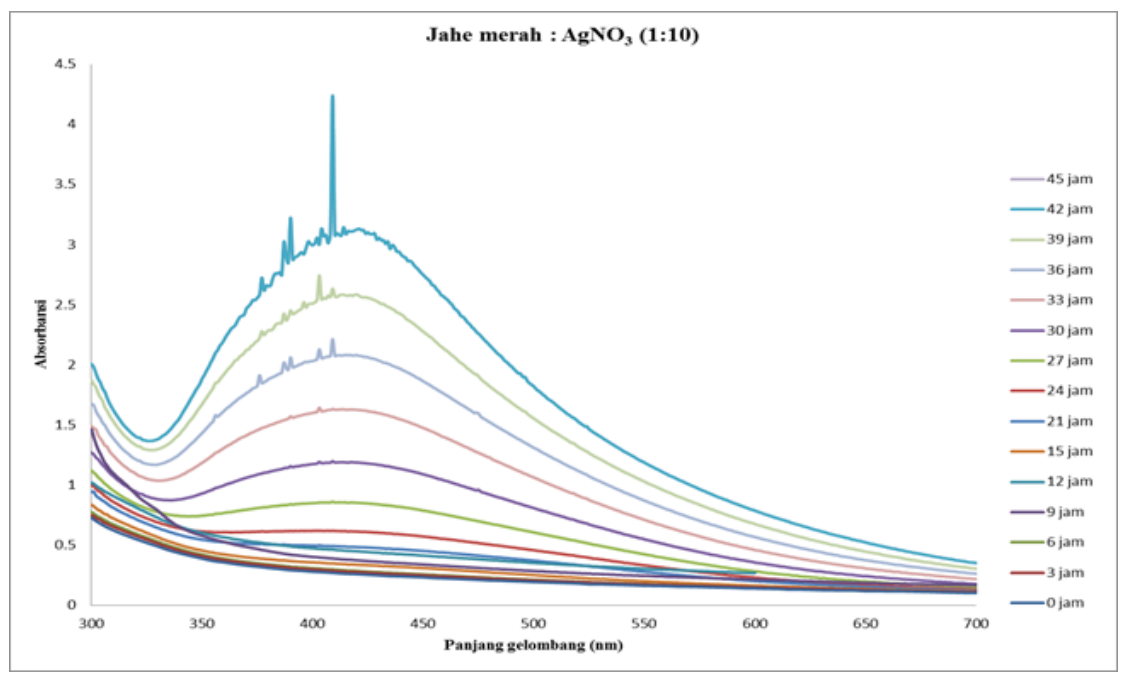

Gambar 2. Spektrum UV-Vis koloid nanopartikel perak terhadap fungsi waktu untuk rasio ekstrak: $\mathrm{AgNO}_{3} \quad$ 1:10 pada sintesis tanpa pengadukan. 

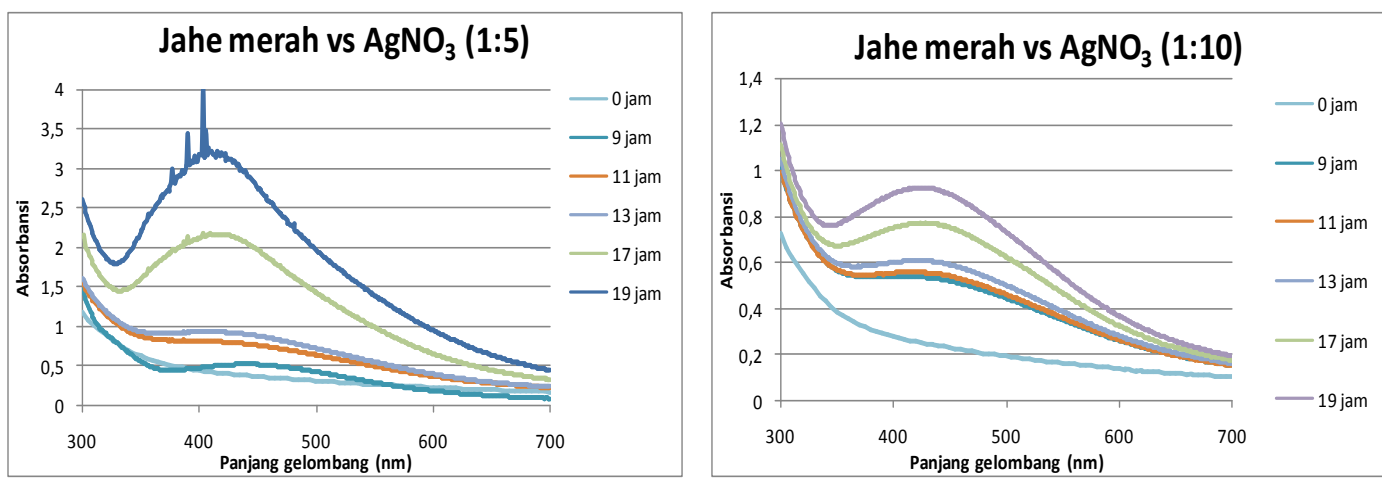

Gambar 3. Spektrum UV-Vis koloid nanopartikel perak terhadap fungsi waktu untuk rasio ekstrak: $\mathrm{AgNO}_{3} \quad$ 1:5 dibandingkan dengan 1:10 pada sintesis dengan pengadukan

Saat terbentuk nanopartikel perak, nilai absorbansi semakin besar dengan semakin bertambahnya waktu kontak. Nilai absorbansi yang meningkat merupakan indikator bahwa nanopartikel perak yang terbentuk semakin bertambah (Handayani dkk. 2010). Nilai absorbansi spektrum meningkat sampai pada jam ke-19 pengadukan dalam pegamatan spektrum UV-VIS. Menurut Bakır et al. (2011), pengaruh pengadukan cenderung mempercepat reaksi antara prekursor dan pereduksi, sehingga nilai absorbansi pada biosintesis nanopartikel perak dengan pengadukan lebih besar daripada dibiarkan saja.

Beberapa spektrum terlihat bergerigi yang menunjukkan terjadinya proses aglomerasi dalam sistem koloid. Aglomerasi menyebabkan distribusi partikel koloid tidak merata. Secara visual aglomerasi ditandai dengan perubahan warna yang semakin pekat dan terbentuknya endapan (penggumpalan). Berdasarkan spekrum UV-Vis, aglomerasi dapat diketahui dengan bentuk spektrum yang bergerigi dan terjadinya pergeseran panjang gelombang ke arah panjang gelombang yang besar.

Aglomerasi adalah pembentukan grup partikel (aggregat) yang terikat satu sama lain dengan gaya van der Waals atau gaya intermolekular lainnya. Aglomerasi disebabkan karena koloid mempunyai sifat kinetik yaitu gerak Brown. Gerak Brown adalah pergerakan acak (random) partikel-partikel koloid di dalam cairan atau gas, yang disebabkan oleh tumbukan dengan molekul dari lingkungan mediumnya. Adanya gerak Brown menyebabkan partikel koloid nanopartikel perak mampu bergerak (menyebar/difusi) dari daerah dengan konsentrasi tinggi ke daerah dengan konsentrasi yang lebih rendah dari fase terdispersi. Gaya gravitasi menyebabkan partikel koloid nanopartikel perak terdispersi tersedimentasi ke bawah. Partikel-partikel koloid nanopartikel perak yang menetap di bawah karena pengaruh gravitasi. Sistem koloid $(\mathrm{nm}-\mu \mathrm{m})$ memerlukan gaya yang lebih kuat dari gravitasi untuk mencegah terbentuknya agregat. Sifat kinetik koloid ini dapat digunakan untuk menentukan massa molekul dari koloid nanopartikel perak (Bhattacharyya \& Gupta 2008). Oleh karena itu, sebaiknya digunakan agen penstabil untuk mencegah aglomerasi seperti polianilin, poliakrilonitril, polietilen glikol, polisakarida, selulosa, gelatin, dan kanji (Ravindran et al. 2005).

\section{KESIMPULAN}

Ekstrak air rimpang jahe merah dapat digunakan sebagai pereduksi dalam biosintesis nanopartikel perak. Sintesis pada suhu ruang dengan pengadukan memberikan waktu sintesis yang lebih cepat dibandingkan tanpa pengadukan. Absorbansi optimum terlihat pada jam ke 36 rasio 1:10 tanpa pengadukan dan pada perbandingan 1:3 jam ke-17 pengadukan.

\section{DAFTAR PUSTAKA}

Bakır, Ç.C., Şahin, N., Polat, R. \& Dursun, Z. (2011). Electrocatalytic reduction of oxygen on bimetallic copper-gold nanoparticlesmultiwalled carbon nanotube modified glassy carbon electrode in alkaline solution. Journal of Electroanalytical Chemistry. 662(2): 275-280.

Bhattacharyya, K.G. \& Gupta, S.S. (2008). Adsorption of a few heavy metals on natural and modified kaolinite and montmorillonite: a review. Advances in Colloid and Interface Science. 140(2): 114-131.

Chandran, S.P., Chaudhary, M., Pasricha, R., Ahmad, A. \& Sastry, M. (2006). Synthesis of gold nanotriangles and silver nanoparticles using Aloe vera plant extract. Biotechnology Progress. 22(2): 577-583.

Elumalai, E.K., Prasad, T.N.V.K.V., Nagajyothi, P.C. \& David, E. (2011). A bird's eye view on biogenic silver nanoparticles and their applications. Der Chemica Sinica. 2(2): 88-97.

Fedlheim, D.L. \& Foss, C.A. (2001). Metal nanoparticles: synthesis, characterization, and applications. CRC press.

Handayani, W., Bakir, I. \& Purbaningsih S. (2010). Potensi ekstrak beberapa jenis tumbuhan 
sebagai agen pereduksi untuk biosintesis nanopartikel perak. Seminar Nasional Biologi Universitas Gadjah Mada. Yogyakarta.

Jirovetz, L., Buchbauer, G., Shafi, M.P. \& Leela, N.K. (2003). Analysis of the essential oils of the leaves, stems, rhizomes and roots of the medicinal plant Alpinia galanga from southern India. Acta Pharmaceutica-Zagreb. 53(2): 7382.

Kelly, K.L., Coronado, E., Zhao, L.L. \& Schatz, G.C. (2003). The optical properties of metal nanoparticles: The influence of size, shape and dielectric environment. Journal of Physical Chemistry B. 107(3): 668-677.

Kesharwani, J., Yoon, K.Y., Hwang, J. \& Rai, M., (2009). Phytofabrication of silver nanoparticles by leaf extract of Datura metel: hypothetical mechanism involved in synthesis. Journal of Bionanoscience. 3(1): 39-44.

Lee, S.Y., Kim, H.J., Patel, R., Im, S.J., Kim, J.H. \& Min, B.R. (2006). Silver nanoparticles immobilized on thin film composite polyamide membrane: characterization, nanofiltration, antifouling properties. Polymers For Advanced Technologies. 18(7): 562-568.

Mallikarjuna, K., Narasimha, G., Dillip, G.R., Praveen, B., Shreedhar, B., Lakshmi, C.S., Reddy, B.V.S. \& Raju, B.D.P. (2011). Green synthesis of silver nanoparticles using Ocimum leaf extract and their characterization. Digest Journal of Nanomaterials and Biostructures. 6(1): 181-186.

Mishra, P. (2009). Isolation, spectroscopic characterization and molecular modeling studies of mixture of Curcuma longa, ginger and seeds of fenugreek. International Journal of PharmTech Research. 1(1): 79-95.

Mitra, B., Visnhudas, D., Sant, S.B. \& Annamalai, A. (2012). Green-synthesis and charactherization of silver nanoparticles by aqueous leaf extract of Cardiospermum helicacabum leaves. Drug Invention Today. 4(2): 340-344.

Nagarajan, R. \& Horton, T.A. (2008). Nanoparticles: Synthesis, Stabilization, Passivation, and
Functionalization. Washington DC : American Chemical Society.

Natta, L., Orapin, K., Krittika, N. \& Pantip, B. (2008). Essential oil from five Zingiberaceae for anti foodborne bacteria. International Food Research Journal. 15(3): 337-346.

Otari, S.V., Patil, R.M., Ghosh, S.J. \& Pawar, S.H. (2014). Green phytosynthesis of silver nanoparticles using aqueous extract of Manilkara zapota (L.) seeds and its inhibitory action against Candida species. Materials Letter. 116: 367-369

Ravindran, P.N., Babu, K.N. \& K.N. Shiva. (2005). Botany and Crop Improvement of ginger. Di dalam: Ravindran, P.N. \& Babu, K.N. (eds). Ginger: The Genus Zingiber. Florida: CRC Press.

Shankar, S.S. (2004). Rapid synthesis of Au, Ag and $\mathrm{Bi}$, metallic $\mathrm{Au}$ Core-Ag shell nanoparticles using neem (Azadirachta indica) leaf broth. Journal of Colloid and Interface Science. 275(4): 496-502.

Sharma, V.K., Ria, A.Y. \& Yekaterina, L. (2009). Silver nanoparticles: Green synthesis and their antimicrobial activities. Advances in Colloid and Interface Science. 145(9): 83-96.

Singh, A., Jain, D., Upadhyay, M.K., Khandelwal, N. \& Verma H.N. (2010). Green synthesis of silver nanoparticles using Argenone mexicana leaf extract and their charactrization. Digest Journal of Nanomaterials and Biostructures. 6(1): 483489.

Solomon, S.D., Bahadory, M., Jeyarajasingam, A.V., Rutkowsky, S.A. \& Boritz, C. (2007). Synthesis and study of silver nanoparticles. Journal Chemistry Education. 84(2): 322-325.

Sondik, I. \& Salopek, S.B. (2004). Silver nanoperticles as antimicrobial agent: A case study on E. coli as a model for gram-negative bacteria. Journal of Colloid and Interface Science. 275(4): 177-182.

Yuharmen, Jose, C. \& Eryanti, Y. (1998). Uji aktivitas antimikrobial minyak atsiri dari akar jahe (Zingiber officinale). Laporan penelitian dosen muda. Ditjen Dikti, Jakarta. 